\title{
Epidermal-growth-factor receptors generate Ras - GTP more efficiently than insulin receptors
}

\author{
Arthur P. R. M. OSTEROP ${ }^{1}$, René H. MEDEMA ${ }^{2}$, Gerard C. M. v. d. ZON ${ }^{1}$, Johannes L. BOS ${ }^{2}$, Wim MÖLLER ${ }^{1}$ \\ and J. Antonie MAASSEN ${ }^{1}$ \\ Laboratory of Protein Synthesis and Hormone Regulation, Sylvius Laboratory, Leiden, The Netherlands \\ Laboratory for Physiological Chemistry, University of Utrecht, The Netherlands
}

(Received October 19/December 11, 1992) - EJB 921476

Activation of the Ras proto-oncogene contributes in general to mitogenic activation of cells.

We show here that epidermal growth factor (EGF) stimulates Ras - GTP formation very efficiently in a variety of cell lines expressing endogenous EGF receptors only. Maximal activation of the receptor converts up to $65 \%$ of cellular p21ras from the GDP form into the active GTPbound state. This efficient activation occurs also in cultured primary human fibroblasts. Maximal insulin-induced Ras - GTP formation is less but in cells overexpressing the insulin receptor a similar high response of Ras - GTP formation is observed after insulin stimulation.

Not only the efficiency but also the kinetics by which the EGF and insulin receptors stimulate Ras - GTP formation are quite distinct. In the Rat-1-derived cell line, H13IR2000, overexpressing both p21Ha-ras and the insulin receptor, the activated insulin receptor generates approximately 1 mol Ras - GTP/mol activated insulin receptor. The activated EGF receptor amplifies the signal, resulting in the activation of approximately $40 \mathrm{~mol} \mathrm{p} 21 \mathrm{ras} / \mathrm{mol}$ receptor.

Moreover, EGF-stimulated generation of Ras . GTP is transient with a maximum after 2 min of hormone stimulation and diminishes to near basal levels within $1 \mathrm{~h}$ whereas the insulin-induced Ras - GTP levels are maximal at 5-10 min and decline only slowly to half-maximal in $1 \mathrm{~h}$.

Desensitization of the EGF pathway by prolonged EGF stimulation, prevents subsequent stimulation of Ras . GTP formation by newly added EGF but not by insulin. Vice versa, in cells preincubated with insulin for $1 \mathrm{~h}$, EGF stimulates Ras - GTP formation to near maximal values. These observations indicate that desensitization by prolonged hormone incubation does not involve inactivation of common signaling intermediates but rather components, specific for each pathway, like the particular receptors. The rapid down regulation of EGF receptors compared to insulin receptors corroborate this possibility.

The observed high potency of EGF receptors to generate Ras - GTP may explain the, in general, stronger mitogenic activity of EGF compared to insulin.

In human tumors, one of the genes which is found frequently to be mutated is the proto-oncogene ras. It encodes a small protein of $21 \mathrm{kDa}$ (p21ras) belonging to a large family of Ras-like proteins [1]. Members of this family have been found throughout the eukaryotic kingdom. Ras proteins participate in very different processes like mitogenic responses, maturation, differentiation and mating signals [27]. The p21ras protein has guanine nucleotide binding properties. When GDP is bound, p21ras is inactive and when GDP is exchanged for GTP the protein is activated. Mutations which keep p21ras stabilized in the active GTP-bound state are often tumorigenic $[8,9]$.

The cycling of wild-type p21ras molecules between the active GTP-bound form and the inactive GDP-bound form seems to involve several processes. p21ras has an intrinsic

Correspondence to J. A. Maassen, Laboratory of Protein Synthesis and Hormone Regulation, Sylvius Laboratory, Wassenaarseweg 72, NL-2333 AL Leiden, The Netherlands

Fax: +3171276125 .

Abbreviations. EGF, epidermal growth factor; $\mathrm{NaCl} / \mathrm{P}_{\mathrm{i}}$, phosphate-buffered saline; $\mathrm{SH} 2$, src homology region 2 . low GTPase activity and thus can reverse its active state into the inactive one. However, cellular proteins have been identified, p120-GAP [10-12] and NF1-GAP [13-16], which enhance this GTPase activity at least 1000 -fold in vitro. Thus they are likely candidates to regulate the hydrolysis of p21ras-bound GTP in vivo $[17,18]$. Also, in cells, proteins are present which enhance the rate of exchange of GDP for GTP on isolated p21ras, thus forming active p21ras [1923]. The activity of these different processes determines the final equilibrium state of the cellular p21ras pool [24].

In situ, the activation of p21ras is stimulated by a variety of activated tyrosine kinase receptors, such as those for insulin, epidermal growth factor, platelet-derived growth factor and neuronal growth factor [25-28]. These different receptors are often present on the same cell where they can interact with proteins having src homology region 2 (SH2) domains like phospholipase- $\mathrm{C} \gamma$, phosphatidylinositol 3-kinase, and p120-GAP [29]. The association constants for interaction of these $\mathrm{SH}$ 2-domain-containing proteins with various tyrosinephosphorylated receptors show substantial differences and this may affect activation of more downstream signaling in- 
termediates like p21ras, and account for the different spectra of biological responses elicited by these hormones [30]. Receptors for EGF and insulin show marked differences in their ability to associate with SH2-domain-containing proteins, e.g. phospholipase- $\mathrm{C} \gamma$ has been found to interact strongly with the EGF receptor and not detectably with the insulin receptor [29]. Also, the spectra of cellular responses of insulin and EGF are different, insulin being particularly potent in inducing metabolic responses [31].

Previously, we showed that each mole of autophosphorylated insulin receptor generates approximately one mole Ras GTP in insulin receptor overexpressing A14 and IR800 cells and that Ras - GTP seems not to be involved in insulinstimulated metabolic signaling in these NIH3T3- and CHO9derived cell lines [32]. Since EGF is known to be more potent in stimulating mitogenic responses than insulin, we compare in this paper the efficiency of EGF- and insulin-mediated Ras . GTP formation in a number of cell lines, including primary human skin fibroblasts. To facilitate quantification of Ras - GTP formation, by insulin and EGF, the Rat1-derived cell line H13IR2000 was constructed which overexpresses wild-type Ha-ras and insulin receptors. This cell line expresses physiological EGF receptor numbers.

\section{EXPERIMENTAL PROCEDURES}

\section{Materials}

All chemicals used were analytical grade. Tissue culture media, sera, G418 and methotrexate were from Gibco. Vector containing wild-type insulin receptor cDNA was kindly provided by Dr. A. Ullrich. Phosphate-free, Dulbecco's modified Eagle medium and bovine insulin were from Sigma. Bovine serum albumin (RIA grade, insulin-free) was from United States Biochemical Corporation. Control monoclonal antibody KT3 [anti-(simian virus-40) large T], rabbit polyclonal antibody anti-(rat $\mathrm{IgG}$ ) and the anti-p21 ras monoclonal antibody, Y13-259, were kindly provided by Dr. A. Zantema. $\left[{ }^{32} \mathrm{P}\right]$ Orthophosphate (carrier-free) and ${ }^{125} \mathrm{I}$-labeled EGF and insulin were from Amersham. Poly(ethyleneimine)-cellulose $\mathrm{F}$ plates were purchased from Merck and protein- $\mathrm{G}-\mathrm{Se}-$ pharose 4 fast-flow beads were from Pharmacia.

$\mathrm{NaCl} / \mathrm{P}_{\mathrm{i}}$ is composed of $137 \mathrm{mM} \mathrm{NaCl}, 3 \mathrm{mM} \mathrm{KCl}$,

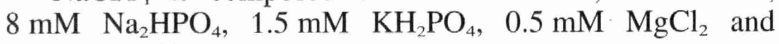
$0.7 \mathrm{mM} \mathrm{CaCl}_{2}$.

\section{Cell lines}

Primary human skin fibroblasts were grown from a forearm skin biopsy of volunteer M. The Hras13 cell line is Rat1-derived and overexpresses wild-type Ha-ras [33]. R1HER cells overexpress the receptor for epidermal growth factor [34]. All cell lines were cultured in Dulbecco's modified Eagle medium with $9 \%$ fetal calf serum ('the medium').

Cell lines overexpressing insulin receptors were constructed by transfecting NIH3T3 and Hras13 cells with a plasmid containing the human wild-type insulin receptor cDNA [35] under control of the simian virus 40 early promotor. The vector contained also a neomycin-resistance gene for selection and a dihydrofolate reductase gene for amplification. Transfection of NIH3T3 cells yielded the A14 cell line and transfection of Hras13 cells yielded the H13IR2000 cell line. The cell lines were maintained in the medium (dialysed against $\mathrm{NaCl} / \mathrm{P}_{\mathrm{i}}$ ) plus $25 \mathrm{nM}$ methotrexate.
Tabie 1. Properties of cell lines used in this study. EGF and insulin binding sites were quantitated by Scatchard analysis except for the value taken from Moran et al. [34]. The numbers of p21ras are according to Downward et al. [33]; n.d., not determined.

\begin{tabular}{lccr}
\hline Cell lines & $\begin{array}{l}\text { EGF } \\
\text { receptors }\end{array}$ & $\begin{array}{l}\text { Insulin } \\
\text { receptors }\end{array}$ & $\begin{array}{l}\text { p21ras } \\
\text { molecules }\end{array}$ \\
\hline & cell ${ }^{-1}$ & & \\
\cline { 2 - 4 } Primary M & & & \\
$\quad$ fibroblasts & 30000 & 1500 & n.d. \\
NIH3T3-A14 & 110000 & 700000 & n.d. \\
Rat-1 & 11000 & 30000 & 27000 \\
Hras13 & 10000 & 29000 & 2600000 \\
H13IR2000 & 40000 & 750000 & 2600000 \\
R1HER & $250000[34]$ & 30000 & 27000 \\
\hline
\end{tabular}

The characteristics of the various cell lines are listed in Table 1. Quantitation of epidermal growth factor and insulin binding sites in cell lines was by Scatchard analysis of hormone binding data.

\section{Cell labeling and analysis of guanine nucleotides bound to p21ras}

The procedures were essentially as described [25]. Experiments were performed at least twice, two replicates per experiment. Celis were incubated with $0.5 \%$ fetal calf serum for $16 \mathrm{~h}$, subsequently labeled for $3 \mathrm{~h}$ with $\left[{ }^{32} \mathrm{P}\right]$ orthophosphate $(0.1-0.2 \mathrm{mCi} / \mathrm{ml})$ and stimulated with EGF and/ or insulin. The cell cultures were rapidly washed and lysed in buffer containing 1\% Triton X-114. After phase separation, by means of a short temperature shift of $0^{\circ} \mathrm{C}$ to $37^{\circ} \mathrm{C}$ [36], the detergent phase was diluted 10-fold with lysis buffer without Triton X-114 but containing $0.5 \%$ sodium deoxycholate and $0.005 \%$ SDS. In addition, $\mathrm{NaCl}$ was added to $500 \mathrm{mM}$ and the detergent phase was used to determine p21ras-bound GTP and GDP.

The diluted Triton X-114 detergent phase was precleared for 15 min with protein-G-Sepharose beads coupled to rabbit anti-(rat $\mathrm{IgG})$ and further processed according to Burgering et al. [25]. In short, the supernatant was incubated for $1 \mathrm{~h}$ with the anti-p21ras monoclonal antibody Y13-259 or the control monoclonal antibody KT3 coupled to protein-GSepharose beads. The immunoprecipitates were collected and washed. GTP and GDP were eluted and separated on poly(ethyleneimine)-cellulose F plates. GTP and GDP spots were visualized by autoradiography and the radioactivity in GTP and GDP was quantitated by liquid scintillation counting. The values were corrected by substraction of background values obtained with the control antibody KT3 [25].

\section{Down regulation of receptors}

H13IR2000 cells were grown in 1.6-cm wells to confluency and cultured in the medium containing only $0.5 \%$ fetal calf serum for $19 \mathrm{~h}$. Subsequently they were incubated with $0.1 \mu \mathrm{M}$ EGF or $1 \mu \mathrm{M}$ insulin at $37^{\circ} \mathrm{C}$. After the indicated time periods, the cells were washed three times with $\mathrm{NaCl} /$ $\mathrm{P}_{\mathrm{i}}\left(4^{\circ} \mathrm{C}\right)$. Receptor-bound hormone was released by incubating the cells for $2 \mathrm{~min}$ with $0.5 \mathrm{M} \mathrm{NaCl}, 0.2 \mathrm{M} \mathrm{NaOAc}$ (pH 4.5) on melting ice, this acid wash was repeated for another $30 \mathrm{~s}$ [37]. The cells were washed twice with $\mathrm{NaCl} / \mathrm{P}$; and once with binding buffer $\left(\mathrm{NaCl} / \mathrm{P}_{\mathrm{i}}, \mathrm{pH} 7.8,1 \%\right.$ bovine 


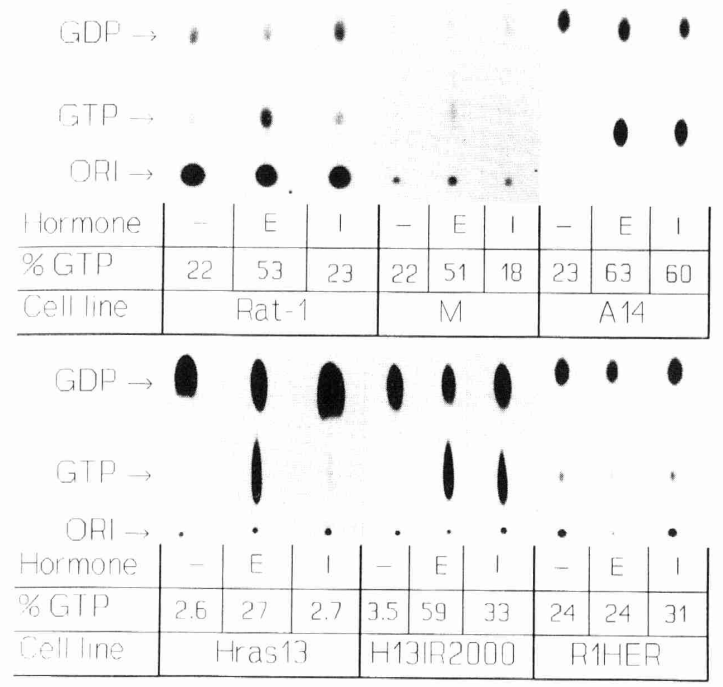

Fig. 1. Hormone-stimulated Ras - GTP formation in a variety of cell lines. A panel of cell lines, listed in Table 1, was serum-starved, labeled with $\left[{ }^{32} \mathrm{P}\right]$ orthophosphate and subsequently incubated for 5 min with either $0.1 \mu \mathrm{M}$ EGF (E) or $1 \mu \mathrm{M}$ insulin (I) or neither $(-)$. p21 ras molecules were immunoprecipitated from the cell lysates and the bound nucleotides were analyzed by thin-layer chromatography and visualized by autoradiography. The radioactivity in the nucleotides was determined and the percentage of GTP was calculated $(\mathrm{ORI}=$ origin $)$. Results for each cell line represent individual experiments.

serum albumin). These pretreated cells were incubated for $2 \mathrm{~h}$ at $4{ }^{\circ} \mathrm{C}$ with ${ }^{125} \mathrm{I}$-labeled EGF $(1 \mathrm{nM}, 173 \mathrm{Ci} / \mathrm{mmol})$ and ${ }^{125} \mathrm{I}$-labeled insulin $(10 \mathrm{nM}, 9.9 \mathrm{Ci} / \mathrm{mmol})$ respectively. After washing the cells three times with $\mathrm{NaCl} / \mathrm{P}_{i}$, they were solubilized in $0.1 \mathrm{M} \mathrm{NaOH}, 0.1 \%$ SDS and bound radioactivity was quantitated by liquid scintillation counting. Aspecific binding of ${ }^{125}$ I-labeled hormone was determined by incubating the cells with a 100-fold molar excess of unlabeled hormone. These values were substracted yielding specific binding values.

\section{RESULTS}

\section{EGF stimulates Ras · GTP formation}

A panel of cells (Table 1) were serum-starved for $16 \mathrm{~h}$, incubated with $\left[{ }^{32} \mathrm{P}\right]$ orthophosphate for $3-4 \mathrm{~h}$ and stimulated for 5 min with $1 \mu \mathrm{M}$ insulin or $0.1 \mu \mathrm{M}$ EGF respectively. p21 ras was extracted from the cell lysates by immunoprecipitation with anti-Ras monoclonal antibody Y13-259 which stabilizes the nucleotide binding. Bound nucleotides were eluted, separated by thin-layer chromatography and visualized by autoradiography (Fig. 1). GTP and GDP spots were scraped from the plates and incorporated ${ }^{32} \mathrm{P}$ was measured in a liquid scintillation counter.

All cell lines which express only endogenous EGF receptors, show a marked increase in Ras - GTP levels upon EGF treatment. Also human (M) primary fibroblasts, grown from a forearm skin biopt, responded to EGF treatment by activating up to $50 \%$ of the Ras molecules.

We found previously that, upon increasing the number of insulin receptors in cells, the insulin-induced Ras - GTP

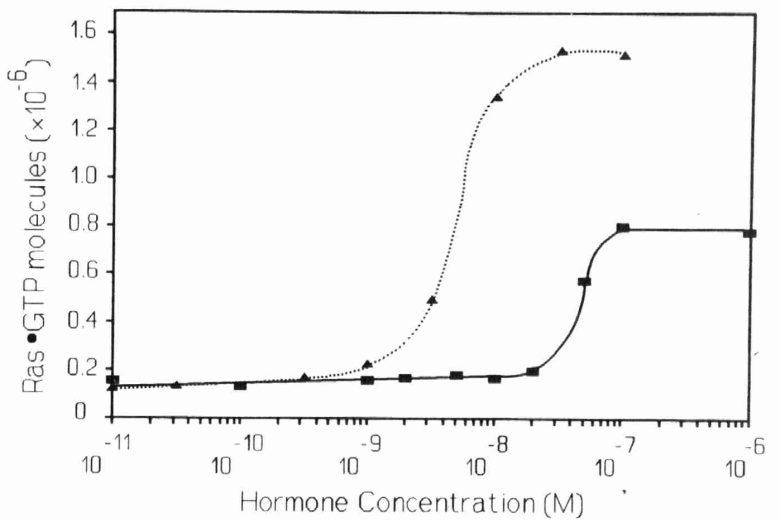

Fig. 2. Hormone-dependent Ras - GTP levels in p21ras and insulin receptor overexpressing cells. H13IR2000 cells, expressing approximately $2600000 \mathrm{p} 21$ ras molecules and 750000 insulin receptors, were serum-starved and labeled with $\left[{ }^{32} \mathrm{P}\right]$ orthophosphate. Cells were stimulated for $5 \mathrm{~min}$ with the indicated concentrations of EGF $(\boldsymbol{\Delta} \cdots \boldsymbol{\Delta})$ or insulin ( $)$. The percentage of Ras · GTP formation is converted into the number of Ras . GTP molecules/cell using the amount of p21 ras/cell as listed in Table 1. This number is plotted against the hormone concentration used. The experiment was performed in duplicate, two replicates/experiment (SD <10\%).

response increased in parallel [32]. It was, therefore, remarkable to note that in the HER14 cells, overexpressing EGF receptors, no significant increase in Ras - GTP formation was induced by EGF [25]. To investigate whether this loss of response is due to the overexpression of EGF receptors, a Rat-1-derived cell line, R1HER, was used having $2.5 \times 10^{5}$ EGF receptors. Compared to Rat- 1 cells, the overexpression of the EGF receptor abolishes EGF-induced Ras - GTP formation as it does in HER14 cells [25] (Fig. 1). Thus it seems that, contrary to the situation with insulin receptors, overexpression of EGF receptor decreases the EGF-induced level of Ras · GTP.

\section{EGF is more potent in p21ras activation than insulin}

In Rat-1 cells, expressing only endogenous receptors for EGF and insulin, hardly any Ras - GTP formation is observed after insulin stimulation (Fig. 1), whereas high Ras - GTP levels are obtained by EGF stimulation. To faculitate quantification of Ras - GTP formation by Insulin and EGF in relation to the number of hormone receptors, cells overexpressing insulin receptors were constructed, using the Rat-1-derived cell line Hras13 as parental cell line, which has an increased expression of wild-type Ha-ras. Due to the high expression of p21ras in this line, quantification of Ras - GTP can be performed at much lower levels of $\left.{ }^{32} \mathrm{P}\right]$ orthophosphate labeling. The resulting H13IR2000 cells were used to compare EGF- and insulin-mediated Ras - GTP generation.

After $\left[{ }^{32} \mathrm{P}\right]$ orthophosphate labeling, the cells were stimulated for 5 min with different concentrations of EGF and insulin respectively. The amount of activated p21ras molecules was plotted against the hormone concentrations (Fig. 2). The H13IR2000 cells are tenfold more sensitive towards EGF stimulation than to insulin and the EGF-induced maximum level of Ras - GTP is about twofold higher compared to insulin stimulation.

Most of the $7.5 \times 10^{5}$ insulin receptors present/ H13IR2000 cell become stimulated by $0.1 \mu \mathrm{M}$ insulin [32] 


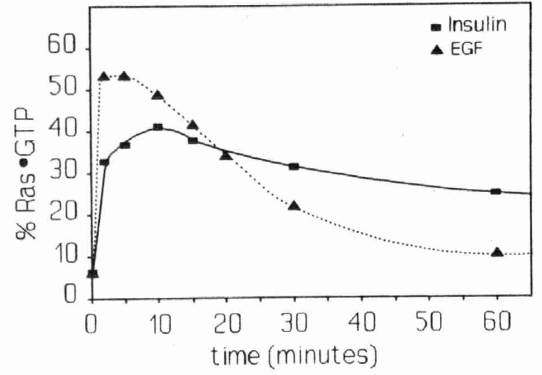

Fig. 3. Hormone-induced Ras - GTP levels in H13IR2000 cells are time-dependent. H13IR2000 cells were serum-starved and labeled with $\left[{ }^{32} \mathrm{P}\right]$ orthophosphate. Subsequently they were stimulated

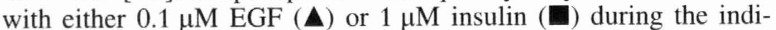
cated periods of time. The percentage of activated p21 ras was calculated and the mean values (SD $<10 \%$ ) were plotted against the different time points.

and these activate about $8 \times 10^{5}$ p21ras molecules. Thus, stimulated insulin receptor molecules activate p21 ras molecules in a near one-to-one fashion. EGF activates up to $16 \times 10^{5}$ p21ras molecules although there are 'only' $4 \times 10^{4}$ EGF receptors present/H13IR2000 cell. Thus, the observation of one EGF receptor activating at least 40 p21ras molecules indicates an amplifying process between the EGF receptor and Ras · GTP formation.

\section{Time dependency for EGF- and insulin-mediated Ras - GTP formation in H13IR2000 cells}

$\left.{ }^{32} \mathrm{P}\right]$ Orthophosphate-labeled H13IR2000 cells were stimulated with $0.1 \mu \mathrm{M}$ EGF or $1 \mu \mathrm{M}$ insulin for various time intervals and the level of Ras . GTP was determined. Fig. 3 shows these data.

EGF stimulates Ras - GTP formation maximally within 2 min whereas insulin activation is slower, with the maximum at $10 \mathrm{~min}$ incubation, despite the tenfold higher insulin concentration. Besides this fast onset of the EGF-induced response, the reponse declines rapidly and reaches near basal levels after $1 \mathrm{~h}$. Insulin-induced Ras - GTP levels persist for longer periods of time and decline slowly.

After 60 min of incubation with EGF, Ras . GTP levels have returned to basal levels (Figs 3 and 4). Subsequent incubation for 5 min with newly added EGF had no effect on Ras - GTP whereas addition of insulin at the 60-min time point restored the percentage of Ras - GTP formed to a value seen with insulin alone. Insulin-pretreated cells also did not activate more $\mathrm{p} 21 \mathrm{ras}$ when incubated additionally with insulin but still responded to EGF giving the Ras - GTP level seen after a 5-min EGF-incubation only (Fig. 4). Thus, the decrease of the Ras - GTP level, after prolonged hormone exposure, is not a consequence of hormone degradation but rather an effect of desensitization of signaling intermediates specific for each hormone-activated pathway.

Stimulation with EGF and insulin together did not show any synergism. Incubation for $5 \mathrm{~min}$ resulted in Ras . GTP levels also seen with EGF alone whereas incubation for $60 \mathrm{~min}$ gave Ras . GTP levels similar to that seen with insulin alone. This is in agreement with a desensitization of the EGF-mediated signaling pathway at the 60 -min time point, leaving the insulin pathway intact.

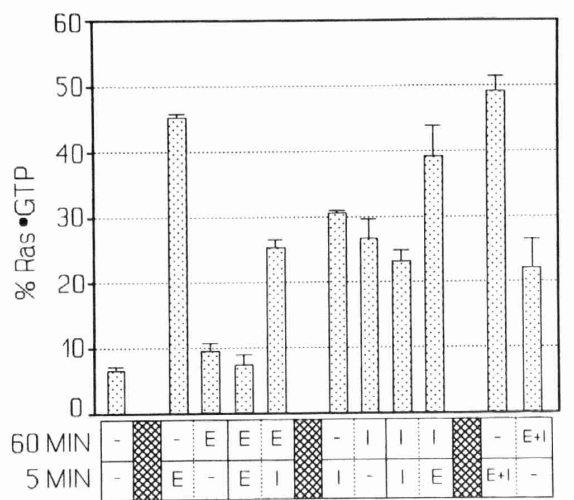

Fig. 4. Desensitization of hormone-induced Ras - GTP formation. H13IR2000 cells were treated as described in the legend of Fig. 3. Cells were kept unstimulated (-) or treated for $5 \mathrm{~min}$ or $60 \mathrm{~min}$ with $0.1 \mu \mathrm{M}$ EGF (E) or $1 \mu \mathrm{M}$ insulin (I), as indicated; - , no hormone. Also, cells were pretreated for $60 \mathrm{~min}$ with EGF and subsequently stimulated for another $5 \mathrm{~min}$ with EGF or insulin. Similarly, cells were pretreated for $60 \mathrm{~min}$ with insulin and subsequently stimulated with insulin or EGF for $5 \mathrm{~min}$. Finally, a group cells were stimulated for 5 or $60 \mathrm{~min}$ with both hormones simultaneously in a cocktail $(E+I)$. The percentages of Ras - GTP were calculated from two independent experiments, two replicates/experiment; the SD is indicated.

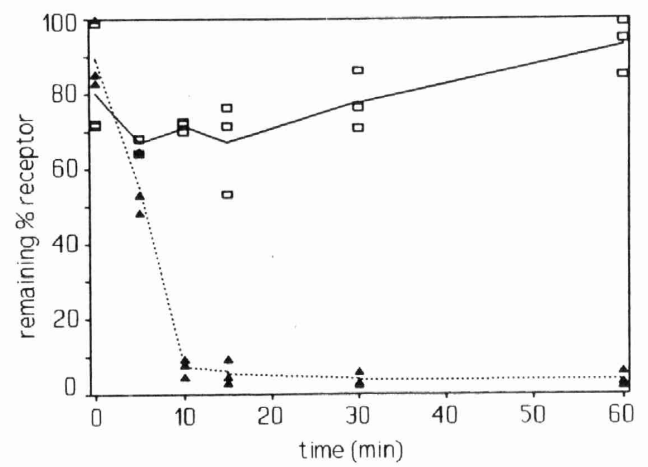

Fig. 5. Time-dependent down regulation of EGF and insulin receptors in H13IR2000 cells. Serum-starved cells were incubated with either $0.1 \mu \mathrm{M}$ EGF $(\mathbf{A} \cdots \mathbf{A})$ or $1 \mu \mathrm{M}$ insulin $(\square-\square)$ for various periods of time. Receptors remaining at the cell surface were freed from bound hormone by an acid wash and subsequently the cells were incubated with ${ }^{125} \mathrm{I}$-labeled hormone for $2 \mathrm{~h}$. The bound radioactivity was determined and expressed as percentage of maximum radioactivity bound without down regulation. The individual values per time point are indicated.

\section{Down regulation of receptors for insulin and EGF in H13IR2000 cells}

To examine whether down regulation of EGF receptors may account for the observed desensitization of EGF-induced Ras - GTP formation, H13IR2000 cells were used to measure the rate of down regulation of the EGF and insulin receptors. Since cells are serum-starved for measuring Ras . GTP levels, we pretreated the H13IR2000 cells in the same way before measuring hormone-induced receptor down regulation.

The insulin receptor hardly becomes down regulated when the cells are incubated with $1 \mu \mathrm{M}$ insulin. Treatment 
with $0.1 \mu \mathrm{M}$ EGF for $5 \mathrm{~min}$ reduces the cell membrane binding sites by $50 \%$ whereas after $10 \mathrm{~min}$ almost all of the EGF receptors have been removed from the cell surface.

The down regulation of EGF receptors on the cell surface precedes the decrease in Ras . GTP level in the cell (Fig. 3).

\section{DISCUSSION}

The present study shows that EGF converts most of the cellular p21ras into the active GTP-bound form. Efficient, EGF-mediated, stimulation of Ras - GTP formation seems to depend on the cell type used, since other groups, using different cell types [26, 27, 38], observe that only a small fraction of cellular p21ras was converted into the GTP state.

When Ras - GTP formation in the EGF-stimulated parental Rat-1 cell line is compared to the Hras13 cell line, which overexpresses p21Ha-ras 100 -fold, a similar high ratio of p21ras-bound GTP/GDP can be obtained. This indicates that in the Rat-1 cells, the EGF receptor, or linked signaling intermediates, are not limiting for Ras - GTP formation. They are even able to generate 50-100-fold more Ras - GTP molecules/cell, within the same period of time, when Ras levels are increased. This situation is in contrast to insulin-mediated Ras - GTP formation. Both in the Rat-1 and Hras13 cell lines insulin stimulation does not give rise to a significant increase in the Ras . GTP levels.

To facilitate comparison of the kinetics of EGF-receptorand insulin-receptor-mediated Ras - GTP formation, we created a Hras13-derived cell line, H13IR2000, which overexpresses both p21ras and the insulin receptor. When H13IR2000 cell are stimulated with insulin the absolute number of Ras - GTP molecules indeed increases compared to the Hras13 or Rat-1 cell line. However, despite the 20fold higher number of insulin receptors, compared to EGF receptors, these H13IR2000 cells are more sensitive to EGF stimulation, the $\mathrm{EC}_{50}$ for EGF being at an approximately tenfold lower concentration than insulin. Moreover, the lower number of EGF receptors yield a maximal Ras - GTP level almost twice as high as obtained by insulin stimulation.

The actual number of EGF receptors/cell is approximately $4 \times 10^{4}$ and the number of p21ras molecules is $26 \times 10^{5}$ of which maximally $60 \%$ becomes activated upon EGF treatment. From these values we calculated that at least 40 p21 ras molecules become activated by one EGF receptor, on average, thus amplifying the incoming EGF signal.

The $7.5 \times 10^{5}$ insulin receptors present per H13IR2000 cell are almost completely activated when the cells are incubated for $5 \mathrm{~min}$ with $0.1 \mu \mathrm{M}$ insulin. These receptors yield approximately $8 \times 10^{5}$ Ras . GTP molecules, i.e. an efficiency of approximately $1 \mathrm{~mol}$ Ras . GTP/mol activated receptor. The same $1: 1$ efficiency is seen also in insulinreceptor-overexpressing cell lines, NIH-A14 and CHOIR800, having normal p21 ras expression levels [32], indicating that elevated p21ras levels do not change the efficiency of the p21 ras activation process. These data show that in the H13IR2000 cell line, as in the Hras13 cells, the EGF receptor is potent in activating p21ras and that a 100 -fold overexpression of p21ras does not result in a situation where the EGF receptor or signaling intermediates become markedly limiting. A different situation is seen with insulin receptors where the receptor number is limiting for yielding high Ras - GTP levels.

Another difference between insulin- and EGF-mediated Ras - GTP formation is the rapid decrease in EGF-induced
Ras - GTP levels compared to insulin. A 1-h incubation with EGF yields almost basal Ras - GTP levels. To investigate whether the cause of the declined Ras - GTP levels originates from hormone degradation, we stimulated the cells after $1 \mathrm{~h}$ additionally with EGF. No rise in Ras - GTP levels was detected. These pretreated cells, however, still responded optimally to stimulations with insulin. Thus the hormone does not become limiting but rather the receptor or signaling intermediates specific for the EGF receptor. In view of the observation that EGF incubation rapidly decreases the number of cell surface receptors to almost zero values and in view of the return of Ras - GTP to basal levels, it seems likely that down regulation of the EGF receptor causes EGF-induced desensitization of Ras - GTP formation. The disappearance of EGF receptors from the cell surface precedes slightly the decrease in Ras - GTP levels. This agrees with a situation where the presence of activated EGF receptors on the cell surface is required for Ras . GTP generation. The insulin receptor is hardly down regulated in H13IR2000 cells, in agreement with the persistent activation of $\mathrm{p} 21 \mathrm{ras}$ by insulin.

It is remarkable that overexpression of EGF receptors causes a decrease in Ras - GTP levels, at least after a 5-min stimulation with EGF. Whether this decrease results from a change in the kinetics of Ras . GTP formation with a maximum at another time point, or indeed is a decreased response in Ras - GTP levels, is currently under investigation.

The observed differences in efficiency and kinetics between EGF- and insulin-mediated Ras - GTP formation may relate to different signaling pathways between the receptor and p21ras or to differences in the kinetics of receptor autophosphorylation and dephosphorylation. The mechanism by which EGF or insulin generates Ras - GTP is unknown but recent (unpublished) experiments by Medema et al. suggest that these hormones act by enhancing the rate of GTP binding rather than by decreasing the GTPase activity of p21ras in cells.

In summary, the results show that the EGF receptor is a much more potent p21ras activator than the insulin receptor. The differences in the efficiency and duration of the Ras . GTP formation, may be linked to the distinct responses elicited by both hormones, like the observed higher mitogenic response of cells when incubated with EGF compared to insulin.

\section{REFERENCES}

1. Hall, A. (1990) Science 249, 635-640.

2. Mulcahy, L. S., Smith, M. R. \& Stacey, D. W. (1985) Nature $313,241-243$.

3. Deshpande, A. K. \& Kung, H.-F. (1987) Mol. Cell. Biol. 7, 1285-1288.

4. Korn, L. J., Siebel, C. W., McCormick, F. \& Roth, R. A. (1987) Science 236, 840-843.

5. Benito, M., Porras, A., Nebreda, A. R. \& Santos, E. (1991) Science 263, 565-568.

6. Hagag, N., Halegoua, S. \& Viola, M. (1986) Nature 319, 680682 .

7. Beitel, G. J., Clark, S. G. \& Horvitz, H. R. (1990) Nature 348, 503-509.

8. Barbacid, M. (1987) Annu. Rev. Biochem. 56, 779-827.

9. Bos, J. L. (1989) Cancer Res. 49, 4682-4689.

10. Trahey, M. \& McCormick, F. (1987) Science 238, 542-545

11. Vogel, U. S., Dixon, R. A. F., Schaber, M. D., Diehl, R. E., Marshall, M. S., Scolnick, E. M., Sigal, I. S. \& Gibbs, J. B. (1988) Nature 335, 90-93. 
12. Trahey, M., Wong, G., Halenbeck, R., Rubinfeld, B., Martin, G. A., Ladner, M., Long, C. M., Crosier, W. J., Watt, K., Koths, K. \& McCormick, F. (1988) Science 242, 1697-1700.

13. Xu, G., O'Connell, P., Viskochil, D., Cawthon, R., Robertson, M., Culver, M., Dunn, D., Stevens, J., Gesteland, R., White, R. \& Weiss, R. (1990) Cell 62, 599-608.

14. Xu, G., Lin, B., Tanaka, K., Dunn, D., Wood, D., Gesteland, R., White, R. Weiss, R. \& Tamanoi, F. (1990) Cell 63, 835-841.

15. Martin, G. A., Viskochil, D., Bollag, G., McCabe, P. C., Crosier, W. J., Haubruck, H., Conroy, L., Clark, R., O'Connell, P., Cawthon, R. M., Innis, M. A. \& McCormick, F. (1990) Cell 63, 843-849.

16. Ballester, R., Marchuk, D., Boguski, M., Saulino, A., Letcher, R., Wigler, M. \& Collins, F. (1990) Cell 63, 851-859.

17. Bollag, G. \& McCormick, F. (1991) Nature 351, 576-579.

18. Basu, T. N., Gutmann, D. H., Fletcher, J. A., Glover, T. W., Collins, F. S. \& Downward, J. (1992) Nature 356, 713-715.

19. West, M., Kung, H.-F. \& Kamata, T. (1990) FEBS Lett. 259, 245-248.

20. Wolfman, A. \& Macara, I. G. (1990) Science 248, 67-69.

21. Downward, J., Riehl, R., Wu, L. \& Weinberg, R. A. (1990) Proc. Natl Acad. Sci. USA 87, 5998-6002.

22. Shou, C., Farnsworth, C. L., Neel, B. G. \& Feig, L. A. (1992) Nature 358, 351-354.

23. Martegani, E., Vanoni, M., Zippel, R., Coccetti, P., Brambilla, R., Ferrari, C., Sturani, E. \& Alberghina, L. (1992) EMBO J. $11,2151-2157$.

24. Li, B.-Q., Kaplan, D., Kung, H.-F. \& Kamata, T. (1992) Science 256, 1456-1459.
25. Burgering, B. M. T., Medema, R. H., Maassen, J. A., Van de Wetering, M. L., Van der Eb, A. J., McCormick, F. \& Bos, J L. (1991) EMBO J. 10, 1103-1109.

26. Satoh, T., Endo, M., Nakafuku, M., Akiyama, T., Yamamoto, T. \& Kaziro, Y. (1990) Proc. Natl Acad. Sci. USA 87, 79267929.

27. Satoh, T., Endo, M., Nakafuku, M., Nakamura, S. \& Kaziro, Y. (1990) Proc. Natl Acad. Sci. USA 87, 5993-5997.

28. Qiu, M.-S. \& Green, S. H. (1991) Neuron 7, 937-946.

29. Cantley, L. C., Auger, K. R., Carpenter, C., Duckworth, B., Graziani, A., Kapeller, R. \& Soltoff, S. (1991) Cell 64, 281-302.

30. Fantl, W. J., Escobedo, J. A., Martin, G. A., Turck, C. W., Del Rosario, M., McCormick, F. \& Williams, L. T. (1992) Cell $69,413-423$

31. Kahn, R. C. (1985) Annu. Rev. Med. 36, 429-451.

32. Osterop, A. P. R. M., Medema, R. H., Bos, J. L., Van der Zon, G. C. M., Moller, D. E., Flier, J. S., Möller, W. \& Maassen, J. A. (1992) J. Biol. Chem. 276, 14647-14653.

33. Downward, J., Gunzburg, J. de, Riehl, R. \& Weinberg, R. A. (1988) Proc. Natl Acad. Sci. USA 85, 5774-5778.

34. Moran, M. F., Polakis, P., McCormick, F., Pawson, T. \& Ellis, C. (1991) Mol. Cell. Biol. 11, 1804-1812.

35. Riedel, H., Dull, T. J., Schlessinger, J. \& Ullrich, A. (1986) Nature 324, 68-70.

36. Bordier, C. (1981) J. Biol. Chem. 256, 1604-1607.

37. Sorkin, A., Helin, K., Waters, C. M., Carpenter, G. \& Beguinot, L. (1992) J. Biol. Chem. 267, 8672-8678.

38. Gibbs, J. B., Marshall, M. S., Scolnick, E. M., Dixon, R. A. F. \& Vogel, U. S. (1990) J. Biol. Chem. 265, 20437-20442. 